\title{
Higher Education Development, Regional Economic Growth and Opening to the Outside World
}

\author{
Yadi Guo ${ }^{1}$ \\ ${ }^{1}$ School of Transportation Science and Engineering, Civil Aviation University of China, Tianjin, China \\ Correspondence: Yadi Guo, School of Transportation Science and Engineering, Civil Aviation University of \\ China, Tianjin 300300, China. E-mail: 2019071052@ cauc.edu.cn
}

Received: January 10, 2022

Accepted: January 25, 2022

Online Published: January 27, 2022

doi:10.20849/abr.v7i1.994

URL: https://doi.org/10.20849/abr.v7i1.994

\begin{abstract}
The development of higher education and opening to the outside world are important factors in promoting China's economic growth. On the basis of clarifying the relationship between the three, based on the economic and social statistics of 290 prefecture-level and above cities in China from 2003 to 2018, this paper constructs a panel model to test the role of higher education development on regional economic growth and the mediating role of urban opening up between the two. The study found that: in the past 15 years, the improvement of the development level of higher education can not only directly promote the growth of the regional economy, but also indirectly promote the growth of the regional economy by improving the level of urban opening to the outside world. It is suggested that the high-quality development of higher education should be continuously promoted, and the opening-up efforts should be increased in order to achieve the strategic goal of high-quality economic and social development.
\end{abstract}

Keywords: higher education, regional economy, opening to the outside world, intermediary role

\section{Introduction}

As the state attaches great importance to higher education, China's higher education has developed rapidly in recent years. It has now entered the stage of popularization, and will enter a stage of high-quality development in the future. As of 2020, the number of regular colleges and universities has reached 2,738, and the number of regular undergraduate and junior college students has reached 7,971,991. The improvement of the development level of higher education can supply a large number of high-quality labor force to the society, promote the improvement of the level of human capital in the region, and is a key factor for the development of the regional economy. The level of China's opening to the outside world is also continuously improving, and the attractiveness of foreign investment is constantly increasing. The actual use of foreign direct investment in 2020 is 1 trillion yuan, which has a positive impact on China's economic development.

Schultz's human capital theory believes that the accumulation of human capital is the source of social and economic growth, and the human capital formed by education accounts for a high proportion of the contribution to economic growth. Bao Shuimei et al. calculated the contribution rate of higher education to economic development in China from 2001 to 2019 (Bao, S.-M., \& Chen, Q.-P., 2021). Cai Wenbo et al. studied the coupling relationship between higher education, technological innovation and economic development (Cai, W.-B., Zhao, Z.-Q., \& Yu, X., 2022). By constructing a spatial econometric model, Li Zheng et al. found that higher education has a significant spatial spillover effect on regional economic growth (Li, Z., \& Wang, H.-D., 2021). Yan Yaqi and Zhang Cong studied the influence of educational human capital level on economic growth in different provinces (Yan, Y.-Q., 2021; Zhang, C., 2021). Zhang Yifan studied the impact of higher education on urban economic development (Zhang, Y.-F., 2021). Yang Yi et al. verified that higher education can cultivate high-level human capital, and then promote regional economic development (Yang, Y., Hu, J.-N., \& Tan, N., 2021).

\section{Theoretical Analysis and Research Hypotheses}

The three exogenous variables of the neoclassical economic growth model are capital stock, labor efficiency and labor input level. The endogenous economic growth model is based on the neoclassical economic growth model, and further proposes that technological innovation is the source of economic growth. In his research, Lucas 
regards human capital as a key production factor alone, which provides an effective impetus for economic growth, and proposes that the acquisition of human capital can be achieved not only in production practice, but also through school education (Lucas, R., 1998; Wang, F.-Y., 2020). Through the analysis of the above models, it can be concluded that human capital is an important factor to promote economic development, and higher education is one of the key ways to improve the quality of labor. The development of higher education can cultivate professional talents, provide high-quality human capital for cities, promote regional knowledge spillover and technological innovation, promote the improvement of the level of specialized division of labor, and improve the efficiency of resource allocation and factor productivity, thereby promoting regional economic growth. From this, hypothesis 1 is put forward:

Hypothesis 1: Higher education development can promote regional economic growth.

The improvement of the development level of regional higher education can drive the improvement of the structure and stock of human capital in the region. The improvement of human capital can drive regional innovation and enhance the vitality of regional economic development; Second, high-quality labor force usually has more professional knowledge and stronger learning ability, and can engage in more creative labor, which helps to reduce the operating cost of the enterprise and improve the profitability of the enterprise (Zhu, H.-P., \& Zhu, W.-T., 2020).Therefore, human capital is an important factor affecting foreign investment decision-making. Foreign investment can bring foreign advanced management experience and technology, promote the progress of management and production level in various industries in my country, improve the efficiency of factor utilization and productivity, and promote industrial upgrading, thereby driving regional economic growth. From this, hypothesis 2 is put forward:

Hypothesis 2: Higher education indirectly promotes regional economic growth through the improvement of the level of opening to the outside world.

\section{Model Building and Variable Selection}

\subsection{Model Building}

In order to explore the relationship between the development level of higher education, economic growth and opening to the outside world, and to test the research hypothesis, this paper uses the stepwise test regression coefficient analysis method to set up the econometric model shown in the following formula. Among them, the level of opening to the outside world is introduced as a mediating variable, and a mediating effect model is set up to deeply analyze the mediating effect of the level of urban opening to the outside world between the level of higher education development and economic growth.

$$
\begin{gathered}
\ln y_{i, t}=C_{1}+\alpha_{1} e d u_{i, t}+\beta_{1} X_{i, t}+\mu_{i}+\varepsilon_{i, t} \\
\text { open }_{i, t}=C_{2}+\delta_{1} e d u_{i, t}+\beta_{2} X_{i, t}+\mu_{i}+\varepsilon_{i, t} \\
\ln y_{i, t}=C_{1}+\alpha_{3} e d u_{i, t}+\alpha_{4} \text { open }_{i, t}+\beta_{3} X_{i, t}+\mu_{i}+\varepsilon_{i, t}
\end{gathered}
$$

Among them, $\operatorname{lny}_{\mathrm{i}, \mathrm{t}}$ represents the logarithm of real GDP per capita in city $\mathrm{i}$ in year $\mathrm{t}$, and $\mathrm{n}$ is the number of cities in period $t ; \alpha_{i}$ represents the influence coefficient of higher education development level and opening level on regional economic development, when $\alpha>0$, it means that it has a positive impact on regional economic development; when $\alpha<0$, it means that it has a negative impact on regional economic development; $\rho$ represents the influence coefficient of higher education development level on the level of opening to the outside world; $\mathrm{X}$ represents the control variable, $\beta$ is the coefficient of various control variables, $\mu_{\mathrm{i}}$ is the individual effect, and $\varepsilon_{\mathrm{it}}$ is the random disturbance term of the model.

\subsection{Variable Selection and Data Sources}

In this paper, the logarithm of the real GDP per capita in each city is used as the explained variable, and on the basis of the previous theoretical analysis, the core explanatory variables and a series of control variables are set up (as shown in Table 1).

(1) $\ln \mathrm{y}_{\mathrm{i}, \mathrm{t}}$ : Economic growth is the explained variable in this paper, and the logarithm of real GDP per capita is used to represent the urban economic growth.

(2) edu $_{\mathrm{i}, \mathrm{t}}:$ The development level of higher education is the explanatory variable of this paper. The proportion of the number of students in ordinary institutions of higher education in the total urban population is used to represent the development level of higher education.

(3) open $n_{i, t}$ : Opening to the outside world is the mediating variable of this paper. This paper uses the logarithm of foreign direct investment to represent the level of opening to the outside world. 
(4) $\operatorname{lnK}_{\mathrm{i}, \mathrm{t}}$ : Capital stock is the control variable of this paper, where $\mathrm{K}_{\mathrm{i}, \mathrm{t}}$ represents the capital stock of the ith region in year $t, K_{i, t-1}$ represents the capital stock of the ith region in year $t-1$, and $\mathrm{I}_{\mathrm{it}}$ represents the ith region's capital stock in year $t-1$ investment in year $t$ in each region. $\mathrm{P}_{\mathrm{it}}$ is the fixed asset investment price index of each city, and $\delta_{\mathrm{t}}$ is the depreciation rate in year t. This article sets the depreciation rate at $10.96 \%$.

(5) $\mathrm{cy}_{\mathrm{i}, \mathrm{t}}$ : The advanced level of industrial structure is the control variable of this paper. The advanced level of industrial structure is a measure of industrial structure upgrading and has an important impact on economic growth. This paper refers to this document and uses the output value of the tertiary industry and the second industry. The ratio of industrial output value is used as a measure of the advanced industrial structure.

(6) $\mathrm{hsr}_{\mathrm{i}, \mathrm{t}}$ : Traffic can promote the positive growth of the regional economy along the line by improving the level of regional accessibility. In this paper, the number of vehicles passing by the high-speed rail in the year is used to characterize the level of regional traffic development.

Table 1. Main variables and their calculation methods

\begin{tabular}{|c|c|c|c|}
\hline Variable name & $\begin{array}{l}\text { Variable } \\
\text { category }\end{array}$ & Variable meaning & Calculation method \\
\hline $\operatorname{lny} y_{i, t}$ & $\begin{array}{l}\text { Explained } \\
\text { variable }\end{array}$ & $\begin{array}{l}\text { Regional economic } \\
\text { development level }\end{array}$ & $\begin{array}{c}\text { Log value of real per-capita GDP in } \\
\text { the region }\end{array}$ \\
\hline$e d u_{i, t}$ & $\begin{array}{l}\text { Explanatory } \\
\text { variables }\end{array}$ & $\begin{array}{l}\text { Higher education } \\
\text { development level }\end{array}$ & $\begin{array}{l}\text { The proportion of students in } \\
\text { ordinary colleges and universities } \\
\text { in the total urban population }\end{array}$ \\
\hline open $_{i, t}$ & $\begin{array}{l}\text { Mediating } \\
\text { variable }\end{array}$ & Level of opening & FDI logarithm \\
\hline $\ln K_{i, t}$ & \multirow{3}{*}{$\begin{array}{l}\text { Control } \\
\text { variable }\end{array}$} & Capital stock & $K_{i, t}=K_{i, t-1}\left(1-\delta_{t}\right)+I_{i, t} / P_{i, t}$ \\
\hline$c y_{i, t}$ & & $\begin{array}{c}\text { Advanced level of industrial } \\
\text { structure }\end{array}$ & $\begin{array}{l}\text { Tertiary industry output } \\
\text { value/second industry output value }\end{array}$ \\
\hline $\mathrm{hsr}_{\mathrm{i}, \mathrm{t}}$ & & $\begin{array}{c}\text { Regional traffic } \\
\text { development level }\end{array}$ & $\begin{array}{l}\text { Annual number of high-speed trains } \\
\text { passing by }\end{array}$ \\
\hline
\end{tabular}

Due to data acquisition reasons, the economic and social data of some prefecture-level administrative units cannot be obtained. After excluding these cities, the panel data of 290 prefecture-level and above cities from 2003 to 2018, the number of students in ordinary colleges and universities, and other types of economic and social data are selected. The data comes from the "China Urban Statistical Yearbook" and the statistical yearbooks of relevant provinces and cities. The high-speed rail data comes from the "National Railway Train Timetable" of each year, and the linear interpolation method is used to fill in the missing samples. Descriptive statistics of the variables are shown in Table 2 below.

Table 2. Variable descriptive statistics

\begin{tabular}{cccccc}
\hline VARIABLES & $\mathrm{N}$ & mean & $\mathrm{sd}$ & $\min$ & $\max$ \\
\hline Lny $_{\mathrm{i}, \mathrm{t}}$ & 4,640 & 10.16 & 0.824 & 7.545 & 12.28 \\
edu $_{\mathrm{i}, \mathrm{t}}$ & 4,640 & 1.553 & 2.177 & 0 & 22.71 \\
open $_{\mathrm{i}, \mathrm{t}}$ & 4,640 & 9.053 & 2.896 & 0 & 14.94 \\
$\operatorname{lnK}_{\mathrm{i}, \mathrm{t}}$ & 4,640 & 14.29 & 1.046 & 10.59 & 18.55 \\
$\mathrm{cy}_{\mathrm{i}, \mathrm{t}}$ & 4,640 & 0.932 & 0.585 & 0.0943 & 9.906 \\
$\mathrm{hsr}_{\mathrm{i}, \mathrm{t}}$ & 4,640 & 37.94 & 92.82 & 0 & 1,020 \\
\hline
\end{tabular}




\section{Empirical Analysis}

Table 3 shows the analysis results of the mediating effect of higher education development, regional economic growth and level of opening to the outside world in China. (1)-(3) are listed as regression results without control variables, and (4)-(6) are listed as added Regression results after controlling for variables.

From the total effect regression results, when the level of opening to the outside world is not considered, it can be found that the improvement of the development level of higher education can promote the growth of regional economy whether the control variable is added or not, but the impact of the development of higher education on economic growth will be overestimated if the control variable is not added. The regression coefficient in column (5) shows that when the level of opening to the outside world is not considered, at the 5\% significance level, the influence coefficient of higher education development level on regional economic growth is 0.1325 . Hypothesis 1 is verified.

Columns (2) and (5) test the mediating effect of the level of opening to the outside world on the development of higher education and economic growth. From the regression results, it can be seen that the development of higher education can significantly promote the level of opening to the outside world in China. After adding the control variable, the proportion of students in ordinary institutions of higher learning in the total urban population will increase by $1 \%$, and the amount of foreign direct investment will increase by $0.1325 \%$.

According to the above regression coefficient results, the mediating effect of the level of opening to the outside world is significant. The regression results of columns (3) and (6) show that after adding the level of opening to the outside world as an intermediary variable, both $\alpha_{3}$ and $\alpha_{4}$ of formula (3) are significant, indicating that the level of higher education development can not only directly and significantly promote regional economic growth, but also It can indirectly promote regional economic growth by improving the level of opening to the outside world. Among them, after adding control variables, the direct effect of higher education development level on promoting regional economic growth is 0.0984 , the indirect effect of higher education development level on promoting regional economic growth through the level of opening to the outside world is 0.0089 , and the ratio of direct effect to indirect effect is 11.02. Hypothesis 2 is verified. Through the sobel test of the mediation effect, it is found that the $\mathrm{P}$ value is much less than 0.05 , which further indicates that the mediation effect is established.

From the regression results of the control variables in column (6), it can be seen that high-speed rail can significantly drive the growth of regional economy. The improvement of the level of chemical division of labor has improved the efficiency of resource allocation and factor productivity, thereby promoting the economic growth of cities. The capital stock shows a significant negative effect, which proves that China's economic development is changing from the original extensional development to the connotative development, and the driving force of its economic development has gradually shifted from the promotion of capital investment and other factors to multi-dimensional factors such as technological innovation. Therefore, the impact of capital stock on regional economic development has not shown a positive impact in recent years. The advanced industrial structure also did not have a positive impact on regional economic growth, indicating that only focusing on the proportion of the service industry over the industry cannot effectively promote the regional economic growth, and it is necessary to adjust the industrial structure of each city according to local conditions.

Table 3. Analysis of regression results

\begin{tabular}{|c|c|c|c|c|c|c|}
\hline & $\begin{array}{c}(1) \\
\text { per-gdp }\end{array}$ & $\begin{array}{c}(2) \\
\text { open }\end{array}$ & $\begin{array}{c}(3) \\
\text { per-gdp }\end{array}$ & $\begin{array}{c}(4) \\
\text { per-gdp }\end{array}$ & $\begin{array}{c}(5) \\
\text { open }\end{array}$ & $\begin{array}{c}(6) \\
\text { per-gdp }\end{array}$ \\
\hline$e^{e d u_{i, t}}$ & $\begin{array}{c}0.2765^{* * *} \\
(0.0511)\end{array}$ & $\begin{array}{c}0.3002 * * * \\
(0.0808)\end{array}$ & $\begin{array}{c}0.2383 * * * \\
(0.0441)\end{array}$ & $\begin{array}{c}0.1073 * * * \\
(0.0361)\end{array}$ & $\begin{array}{c}0.1325 * * \\
(0.0616)\end{array}$ & $\begin{array}{c}0.0984 * * * \\
(0.0322)\end{array}$ \\
\hline open $_{i, t}$ & & & $\begin{array}{c}0.1274 * * * \\
(0.0147)\end{array}$ & & & $\begin{array}{c}0.0674 * * * \\
(0.0155)\end{array}$ \\
\hline $\ln K_{i, t}$ & & & & $\begin{array}{c}-1.1063 * * * \\
(0.2713)\end{array}$ & $\begin{array}{c}-1.1098 * * * \\
(0.2708)\end{array}$ & $\begin{array}{c}-1.0315^{* * *} * \\
(0.2695)\end{array}$ \\
\hline cyi,t & & & & $\begin{array}{c}-0.1236 * * * \\
(0.0470)\end{array}$ & $\begin{array}{c}-0.5271 * * \\
(0.2676)\end{array}$ & $\begin{array}{l}-0.0881^{*} \\
(0.0486)\end{array}$ \\
\hline $\mathrm{hsr}_{\mathrm{i}, \mathrm{t}}$ & & & & $0.0015^{* * *}$ & $0.0020^{* * *}$ & $0.0013^{* * *}$ \\
\hline
\end{tabular}




$\begin{array}{ccccccc} & & & & (0.0004) & (0.0006) & (0.0004) \\ \text { _cons } & 9.7314 * * * & 8.5867 * * * & 8.6378 * * * & 25.8588^{* * *} & 25.1176^{* * *} & 24.1667 * * * \\ & (0.0793) & (0.1255) & (0.1201) & (3.9577) & (3.9869) & (4.0394) \\ \mathrm{N} & 4640 & 4640 & 4640 & 4640 & 4640 & 4640 \\ \mathrm{R} 2 & 0.1498 & 0.0269 & 0.2533 & 0.5499 & 0.0980 & 0.5768\end{array}$

Note: The values in parentheses in the table are standard errors. *, **, and *** indicate significance levels of $10 \%, 5 \%$, and $1 \%$, respectively.

\section{Conclusion}

Based on the panel data of 290 cities from 2003 to 2018, this paper makes a theoretical analysis and empirical test on the macroeconomic impact of higher education in China by constructing an econometric model, and deeply discusses the relationship between the development of higher education, regional economic growth and urban opening-up, so as to provide reference for promoting the quality of urban higher education, and provide decision support for promoting high-quality and sustainable development of regional economy through human capital and opening to the outside world. Through the research of this paper, it is found that the development of higher education can not only directly affect the regional economic growth through its own characteristics, but also indirectly affect the regional economic growth through the transmission path of the level of opening to the outside world. Based on the above research, this paper puts forward the following recommendations:

First, continue to promote the high-quality development of higher education. First of all, clarify the development orientation of each university, vigorously introduce high-level teachers, build high-level research teams, optimize the allocation of scientific research resources, and cultivate research-oriented talents in line with the development of the times. Secondly, increase industry-university-research cooperation, build a cooperation and contact platform between enterprises and various universities, and rely on the platform to create special professional disciplines, so that the school's talent training can be combined with market demand, improve students' practical ability, and cultivate applied talents. At the same time, it is necessary to formulate differentiated higher education training strategies according to regional characteristics, types and levels of colleges and universities, and create high-quality research-oriented and application-oriented universities with their own characteristics.

The second is to increase the intensity of opening to the outside world. First of all, it is necessary to improve the level of education opening to the outside world. On the basis that education is rooted in China and in line with China's national conditions, it should strengthen cooperation with universities around the world and enhance the core competitiveness of higher education globalization. Secondly, by implementing appropriate systems and policies, optimizing the foreign investment environment, actively attracting foreign investment, and expanding the level of opening to the outside world, in order to promote the transformation and upgrading of the industrial structure, enhance the innovation capabilities of various industries, and promote the high-quality development of the Chinese economy. In addition, it is necessary to build an open talent team and focus on cultivating talents with good international quality and global competitiveness.

\section{References}

Bao, S.-M., \& Chen, Q.-P. (2021). Comparative Analysis of the Contribution Rate of Higher Education to Economic Development among my country's Regions: An Empirical Study Based on China's Provincial Panel Data in the Past 20 Years. Journal of Lanzhou University (Social Science Edition), 49(5), 16-27.

Cai, W.-B., Zhao, Z.-Q., \& Yu, X. (2022). Research on the dynamic coupling of higher education, technological innovation and economic development in the Chengdu-Chongqing economic circle. Journal of Southwest University (Social Science Edition), 48(1), 130-143.

Gao, X.-J. (2018). Foreign Direct Investment, Human Capital Structure and my country's Regional Innovation Performance. Journal of China Women's University, 30(3), 116-123.

Huang, L.-X., Wang, Z., \& Wang, X.-B. (2021). Research on the Influence and Mechanism of Foreign Direct Investment by Local Economic Growth Targets. International Economic and Trade Exploration, 37(2), 51-66.

Li, Z., \& Wang, H.-D. (2021). Spatial agglomeration and spillover effects of higher education on regional economic growth: An empirical study based on the "One Belt, One Road" delineation of provinces. Higher 
Engineering Education Research, (5), 121-127.

Liu, Y.-Y., \& Xing, Y.-S. (2021). The impact of foreign investment on my country's economic growth and industrial structure. Northern Economic and Trade, (9), 29-33.

Lucas, R. (1998). On the mechanics of economic development. Journal of Monetary Economics, 22.

Noorbakhsh, F., Paloni, A., \& Youssef, A. (2001). Human Capital and FDI Inflows to Developing Countries: New Empirical Evidence. World Development, 29. https://doi.org/10.1016/S0305-750X(01)00054-7

Tian, X.-Q., \& Zeng, W.-F. (2021). An Empirical Analysis of the Promotion of Economic Growth by Foreign Direct Investment in ASEAN Countries. Cooperative Economy and Technology, (14), 71-73.

Wang, F.-Y. (2020). Research on the Economic Impact Effect of Higher Education Investment in Western China.

Yan, Y.-Q. (2021). Research on the Influence of Educational Human Capital Level on Economic Growth in Liaoning Province. Liaoning University.

Yang, Y., Hu, J.-N., \& Tan, N. (2021). The Spillover Study on the Impact of Higher Education Investment and Human Capital Structure on Regional Economic Growth. Heilongjiang Higher Education Research, 39(9), $36-44$.

Ying, S., Hou, G.-H., \& Xie, L. (2008). Foreign Direct Investment, Human Capital and China's Economic Growth: An Empirical Analysis Based on Cointegration Theory. Journal of Guangdong Business School, (2), 14-20.

Zhang, C. (2021). The measurement of educational human capital level in Henan Province and its impact on economic growth. Liaoning University.

Zhang, Y.-F. (2021). Analysis of the impact of higher education on urban economic development. China Market, (27), 29-30.

Zhou, Q. (2021). Research on the relationship between foreign direct investment, technological innovation and economic development. Quality and Market, (22), 175-177.

Zhu, H.-P., \& Zhu, W.-T. (2020). Human capital, labor prices and FDI inflows-Analysis based on market panel data. Journal of Shanghai Lixin Institute of Accounting and Finance, 32(5), 82-94.

\section{Copyrights}

Copyright for this article is retained by the author(s), with first publication rights granted to the journal.

This is an open-access article distributed under the terms and conditions of the Creative Commons Attribution license (http://creativecommons.org/licenses/by/4.0/). 